\title{
ANALISIS IMPLEMENTASI STANDAR PROSES PEMBELAJARAN GURU MATEMATIKA
}

\author{
${ }^{1}$ Nunung Sobarningsih, ${ }^{2}$ Hamdan Sugilar, ${ }^{3}$ Rikrik Nurdiansyah \\ ${ }^{1,2,3}$ Prodi Pendidikan Matematika, UIN Sunan Gunung Djati Bandung, JL AH Nasution \\ No. 105 Bandung \\ e-mail: hamdansugilar@uinsgd.ac.id
}

\begin{abstract}
Abstrak
Tujuan penelitian adalah untuk mengetahui tingkat kesesuaian pelaksanaan pembelajaran matematika pada prodi pendidikan matematika dengan kemampuan guru alumni prodi pendidikan matematika dalam melaksanakan standar proses pembelajaran. Keberhasilan proses pembelajaran merupakan hal utama yang didambakan dalam melaksanakan pendidikan di sekolah sebagai upaya meningkatkan keberhasilan dalam pembelajaran matematika. Kemampuan menguasai materi dan strategi pembelajaran merupakan dua hal kemampuan guru yang tidak dapat ditawar lagi. Melalui penguasaan materi pelajaran akan menghasikan pemahaman dan penguasaan kognitif siswa dengan baik, siswa memahami dan memaknai belajar matematika dengan bermakna dan menyenangkan. Pada pembelajaran siswa merasa nyaman dan tertantang, mereka asyik dan enjoy dalam belajar dikarenakan ketepatan strategi, model, dan metode mengajar yang tepat dan baik. Hal ini dapat terwujud salah satunya apabila guru menyiapkan standar proses pembelajaran dengan tepat, baik dan terukur. Diharapkan alumni pendidikan matematika terampil dan mampu melaksanakan standar proses pembelajaran dan menerapakn ilmu yang telah diperoleh waktu perkuliahan, sebagai feed back juga untuk peningkatan kualitas prodi pendidikan matematika. Hasil penelitian diperoleh bahwa umumnya guru matematika (alumni prodi pendidikan matematika) mampu membuat RPP namun belum mampu mengembangkan pada kegiatan inti pembelajaran, penerapan model yang tercantum RPP belum sepenuhnya dilakukan bahkan belum sampai pada evaluasi dan guru kurang menekankan aspek pengembangan karakter atau akhlak mulia.
\end{abstract}

Kata Kunci: analisis impelementasi, standar proses, matematika

\begin{abstract}
The purpose of the study was to determine the suitability of the implementation of mathematics learning in mathematics education study programs with the ability of alumni teachers of mathematics education study programs in implementing the standard learning process. The success of the learning process is the main thing that is coveted in implementing education in schools as an effort to increase success in mathematics learning. The ability to master the material and learning strategies are two things that the teacher's abilities are not negotiable anymore. Through mastering the subject matter will produce students' cognitive understanding and mastery well, students understand and interpret learning mathematics meaningfully and pleasantly. In learning students feel comfortable and challenged, they are absorbed and enjoy learning because of the precision of strategies and models, and the right and good teaching methods. This can be realized, one of which is if the teacher prepares the standard learning process appropriately, well and measurably. It is expected that skilled mathematics education alumni and able to carry out the standard of the learning process and receive the knowledge gained during the lecture, as a feed back as well as to improve the quality of mathematics education study programs. The results showed that generally mathematics teachers (mathematics education study program alumni) were able to make lesson plans but had not been able to develop core learning activities, the implementation of the model listed in the lesson plan had not yet been fully implemented and had not even been evaluated and the teacher lacked the character development or noble character.
\end{abstract}

Keywords: implementation analysis, process standards, mathematics

\section{PENDAHULUAN}

Kemampuan matematis yang tercantum dalam Kurikulum Tingkat Satuan Pendidikan dan Kurikukum 2013 sejalan dengan kemampuan matematis yang disusun oleh National of Council Teachers of Mathematics (NCTM) (2000: 402) yaitu: 
“...ability to apply their knowledge to solve problems within mathematics and in other disciplines, ability to use mathematical language to communicate ideas, ability to reason and analyze, knowledge and understanding of concepts and procedures, disposition toward mathematics, understanding of the nature of mathematics, integration of these aspects of mathematical knowledge".

Pembelajaran matematika diharapkan berakhir dengan sebuah pemahaman siswa yang komprehensif. Pemahaman siswa yang diharapkan tidak hanya sekedar memenuhi tujuan pembelajaran matematika secara substantif saja namun juga diharapkan munculnya efek iringan dari pembelajaran tersebut. Efek iringan dari pembelajaran matematika menurut TIM MKPBM (2001: 254) adalah: 1) Lebih memahami keterkaitan antar topik matematika; 2) Lebih menyadari akan pentingnya matematika bagi bidang lain; 3) Lebih memahami peranan matematika dalam kehidupan; 4) Lebih mampu berpikir logis, kritis dan sistematis; 5) Lebih kreatif dan inovatif dalam mencari solusi pemecahan sebuah masalah; 6) Lebih peduli pada lingkungan sekitarnya.

Kemampuan matematika yang harus dimiliki oleh siswa, diharapkan muncul dan lahir melalui proses pembelajaran yang dikemas oleh guru yang berperan sebagai aktor utama terjadinya proses pembelajaran. Smith (Juano: 2016:47) menyatakan "peran guru sebagai pengajar atau fasilitator, sedangkan peserta didik merupakan individu yang belajar, sebab sebuah pembelajaran yang efektif akan terjadi apabila seorang guru bisa memanage proses pembelajaran secara efektif".

Suwarsono (2013:22) mengungkapkan "model pembelajaran apapun baiknya tidak akan berarti jika tidak dengan sentuhan kemampuan dan keyakinan pendidik”. Sehingga peranan guru dalam menyusun proses pembelajaran di kelas sangat dipengaruhi oleh keyakinan dan pengetahun terhadap konsep. Kualitas pemahaman dan persepsi siswa terhadap matematika sangat bergantung pada guru. Frengky (2008:162) menyebutkan “...guru yang memberikan pembelajaran yang tepat, yang sesuai dengan dunia anak-anak, akan menciptakan siswa yang senang dengan pelajaran matematika". Penyataan tersebut bermakna bahwa selain penguasaan konsep tentang matematika guru juga perlu menguasai tentang faktor psikologi perkembangan siswa pada jenjang pendidikan. Sehingga Frengky merekomendasikan agar guru melaksanakan pembelajaran sesuai dengan proses perkembangan kognitif sebagaimana kosep dari Piaget.

Permendiknas No 16 Tahun 2007, menjelaskan pengetahuan guru matematika atau disebut dengan kompetensi guru yang meliputi empat hal yaitu kompetensi: 1). pedagogik yang meliputi kemampuan dan pengatahuan guru dalam melaksanakan proses pembelajaran dengan metode pembelajaran, teori-teori belajar yang bersifat mendidik, pengembangan kurikulum 
dan potensi peserta didik serta pemanfaatan media-media pembelajaran. Sehingga jalannya pembelajaran menjadi lebih efektif dan potensi peserta didikpun bisa dimaksimalkan dengan baik, 2). kepribadian yang meliputi tingkah laku yang sesuai dengan norma-norma yang berlaku. Sehingga guru menjadi teladan bagi siswa, 3). sosial yang meliputi kemampuan berkomunikasi dengan lingkungan pendidikan maupun luar pendidikan, dan 4). profesional meliputi penguasaan terhadap materi, standar kompetensi, dan kompetensi dasar matematika, penggunaan teknologi untuk pembelajaran matematika, serta selalu mengembangkan kemampuan diri.

Menurut Juano (2016:47), keberhasilan proses pembelajaran merupakan hal utama yang didambakan dalam melaksanakan pendidikan di sekolah. Sebagai upaya meningkatkan keberhasilan dalam pembelajaran matematika pada masa sekarang, telah banyak dikembangkan metode-metode pembelajaran yang berpusat pada peserta didik. Sehingga tercipta pembelajaran student centre. Kemampuan guru yang beragam dan karakteristik peserta didik juga berbeda pada tiap daerah, maka untuk menyamakan persepsi pelaksanaan pembelajaran disusunlah Permendikbud No 65 Tahun 2013, yaitu Standar Proses Pembelajaran. Dalam Permendiknas tersebut diterangkan bahwa:

"Proses Pembelajaran pada satuan pendidikan diselenggarakan secara interaktif, inspiratif, menyenangkan, menantang, memotivasi peserta didik untuk berpartisipasi aktif, serta memberikan ruang yang cukup bagi prakarsa, kreativitas, dan kemandirian sesuai dengan bakat, minat, dan perkembangan fisik serta psikologis peserta didik. Untuk itu setiap satuan pendidikan melakukan perencanaan pembelajaran, pelaksanaan proses pembelajaran serta penilaian proses pembelajaran untuk meningkatkan efisiensi dan efektivitas ketercapaian kompetensi lulusan."

Mencetak guru matematika yang memiliki berbagai kemampuan tersebut di atas merupakan tuntutan bagi Lembaga Pendidikan Tenaga Kependidikan (LPTK). LPTK melaui program studi pendidikan matematika sebagai lembaga yang mendidik, mempersiapkan dan membina mahasiswa calon guru matematika harus menanamkan prinsip pembelajaran yang digunakan dalam proses belajar mengajar kepada mahasiswa yang akan menjadi salah satu aktor utama pembelajaran. Melalui berbagai mata kuliah metodologi pembelajaran, praktik mengajar (Micro Teaching) kemudian ditambah praktik pengalaman lapangan (PPL), seharusnya mahasiswa calon guru matematika sudah siap mengajarkan matematika dengan berbagai tantangan yang dihadapi baik dari pemerintah sebagai pemangku kebijakan maupun dari masyarakat sebagai pengguna lembaga pendidikan yang dikelola.

Kondisi ideal yang diharapkan oleh program studi belum tercapai sepenuhnya, berdasarkan studi pendahuluan melalui observasi dan wawancara dengan mahasiswa PPL, 
mahasiswa mendapatkan kesulitan untuk mengaplikasikan kemampuan mengajar mereka dikarenakan kondisi, situasi dan fasilitas dari masing-masing sekolah berbeda. Sehingga mahasiswa calon guru matematika merasa belum optimal. Sementara itu hasil wawancara dengan dosen, mengungapkan bahwa saat mahasiswa melaksanakan praktik mengajar sudah terlihat bahwa mahasiswa kurang maksimal dalam mengelola proses pembelajaran dari segi perencanaan, pelaksanaan, penilaian dan penyampaian materi. Sehingga mahasiswa terjebak dalam kegiatan rutin pembelajaran yaitu memeriksa tugas, memberi materi baru kemudian memberi tugas lagi.

Sobel dan Maletsky (2004:1) menyatakan bahwa banyak guru matematika yang mengawali pembelajaran dengan memeriksa/ membahas tugas yang lalu kemudian memberi materi baru diakhiri dengan memberi tugas. Pendekatan seperti ini terus dilakukan secara rutin yang pada akhirnya dapat dikatagorikan menjadi tiga M yaitu Membosankan, Membahayakan dan Merusak seluruh minat siswa. Jika terjadi kegiatan rutin seperti ini maka ditakutkan minat siswa terhadap matematika akan menurun.

Sebagai seorang calon guru, mahasiswa pendidikan matematika perlu mengasah berbagai keterampilan dalam mengajar, seperti yang diungkapkan oleh Diah (2015:393):

"keterampilan yang perlu ditingkatkan dalam membuka pelajaran adalah menyampaikan tujuan pembelajaran yang akan dicapai, keterampilan yang perlu ditingkatkan mengadakan variasi mengajar adalah menggunakan variasi alat atau media yang dapat diraba dan digerak-gerakkan (dimanipulasi) siswa dan keterampilan dalam mengadakan variasi gerakan badan (berupa gestures) untuk memperjelas pelajaran matematika. Keterampilan yang perlu ditingkatkan dalam menjelaskan adalah menggunakan bahasa yang jelas dan berbicara lancar (tidak tersendat-sendat)"

Oleh karena itulah, peneliti tertarik untuk melakukan penelitian yang berjudul "Analisis Implementasi Standar Proses Pembelajaran dalam Praktik Mengajar Mahasiswa Pendidikan Matematika".

\section{METODE PENELITIAN}

Penelitian ini menggunakan metode penelitian kualitatif. Penelitian kualitatif dipilih karena beberapa pertimbangan yaitu: a). penelitian ini berusaha melihat perilaku, kebiasaan dan kemampuan mempraktekan mengajar mahasiswa pendidikan matematika. b). Penelitian ini lebih bersifat induktif, artinya peneliti berusaha mendeskripsikan permasalah berdasarkan pada data yang terbuka bagi penelitian lebih lanjut. c). Penelitian ini dilakukan dalam situasi yang alamiah dan mengutamakan data yang bersifat kualitatif. d). Penelitian ini dilakukan tanpa adanya perlakuan khusus pada subjek.

Prima, Vol. 3, No. 1, Januari 2019, 67-84. 
Subjek penelitian adalah alumni pendidikan matematika UIN Sunan Gunung Djati Bandung tahun akademik yang menjadi guru matematika di wilayah priangan timur Jawa Barat. Lembar observasi, video, RPP, wawancara dan dokumentasi.

Model pengolahan data yang digunakan dalam penelitian ini menggunakan Model Interactive dari Miles and Huberman yaitu analisis data dilakukan pada saat pengumpulan data berlangsung, dan setelah selesai pengumpulan data dalam periode tertentu. Aktivitas dalam analisis data meliputi pengumpulan data, reduksi data, penyajian data dan verifikasi data seperti dilukiskan pada Gambar 1.

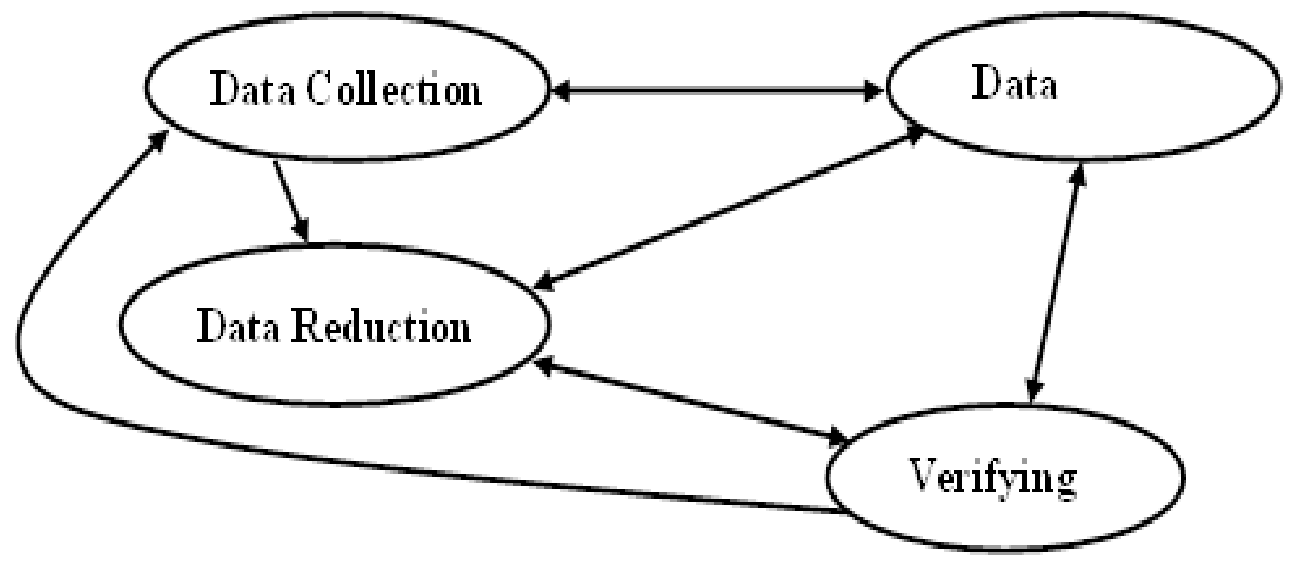

Gambar 1. Pengolahan data Model Interactive ( Miles and Huberman )

\section{a. Data Collection (Pengumpulan Data)}

Data dikumpulkan dengan berbagai teknik pengumpulan data (Trianggulasi), yaitu merupakan penggabungan dari berbagai macam teknik pengumpulan data baik wawancara, observasi maupun dengan menggunakan dokumentasi. Semakin banyak data yang terkumpul, maka hasil penelitian yang didapat semakin bagus.

\section{b. Data Reduction (Reduksi Data)}

Data yang diperoleh dari lapangan jumlahnya cukup banyak, untuk itu maka data perlu dicatat secara teliti dan rinci. Kemudian data dirangkum, dipilih hal-hal yang pokok, difokuskan pada hal-hal yang penting dan dicari tema serta polanya.

Data yang telah direduksi akan memberikan gambaran yang lebih jelas dan mempermudah peneliti untuk melakukan pengumpulan data selanjutnya, dan mencari data berikutnya jika diperlukan. Data-data yang tidak terpakai dibuang, sehingga peneliti lebih fokus pada data yang telah tereduksi.

c. Data display (Penyajian Data)

Setelah data direduksi, maka langkah selanjutnya adalah menyajikan data. Display data dapat dalam bentuk tabel, grafik, chard dan sejenisnya. Melalui penyajian data dalam 
bentuk display, maka data dapat terorganisir dan disusun dalam pola hubungan. Sehingga akan semakin mudah dipahami oleh pihak lain selain peneliti.

Display data dalam penelitian ini dilakukan dalam bentuk uraian singkat, bagan, hubungan antar kategori dan flowchart. Penyajian data dengan menggunakan teks yang bersifat naratif.

\section{d. Verifying (Verifikasi)}

Langkah berikutnya dalam analisis data adalah verifikasi yaitu memverifikasi data dan menarik kesimpulan. Kesimpulan yang diambil harus didukung oleh data-data yang valid dan konsisten, sehingga kesimpulan yang dikemukakan merupakan kesimpulan yang kredibel. Kesimpulan yang diperoleh merupakan jawaban dari fokus penelitian yang telah dirumuskan sejak awal dan dapat berkembang sesuai dengan kondisi yang berada di lapangan. Kesimpulan yang diperoleh juga dapat berupa temuan baru yang belum pernah ada sebelumnya.

\section{HASIL DAN PEMBAHASAN}

1. Standar Proses

Sanjaya (2009:4) menekankan pada beberapa hal tentang pengertian standar proses yaitu:

a. Standar proses pendidikan adalah standar nasional pendidikan, yang berarti standar proses pendidikan berlaku untuk setiap lembaga pendidikan formal pada jenjang pendidikan tertentu di mana pun lembaga pendidikan itu berada secara nasional.

b. Standar proses pendidikan berkaitan dengan pelaksanaan pembelajaran, yang berarti dalam standar proses pendidikan berisi tantangan bagaimana seharusnya proses pembelajaran berlangsung. Dengan demikian standar proses dapat dijadikan pedoman bagi guru dalam pengelolaan pembelajaran.

c. standar proses pendidikan diarahkan untuk mencapai standar kompetensi lulusan (SKL). Dengan demikian, standar kompetensi lulusan merupakan sumber atau rujukan utama dalam menentukan standar proses pendidikan. Maka sebenarnya standar proses pendidikan bisa dirumuskan dan diterapkan manakala telah tersusun standar kompetensi lulusan.

Sanjaya (2009:5), mengatakan bahwa "lemahnya proses pembelajaran yang dikembangkan guru dewasa ini, merupakan salah satu masalah yang dihadapi dunia pendidikan". Sebagai contoh, ada guru yang dalam melaksanakan pengelolaan pembelajarannya dilakukan dengan sungguh-sungguh ada juga guru yang melaksanakannya secara biasa. Guru yang sungguh-sungguh akan dapat menghasilkan kualitas lulusan yang Prima, Vol. 3, No. 1, Januari 2019, 67-84. 
lebih baik dibanding dengan guru yang melakukan pengelolaan pembelajarannya dengan asalasalan.

Standar proses sebagai standar pelaksanaan pembelajaran dapat dipengaruhi dan berhubungan dengan standar-standar lainnya yaitu standar isi, standar kompetensi lulusan, standar penilaian, standar sarana prasarana, standar pendidik dan tenaga kependidikan dan standar pembiayaan. Hubungan itu digambarkan sebagai berikut:

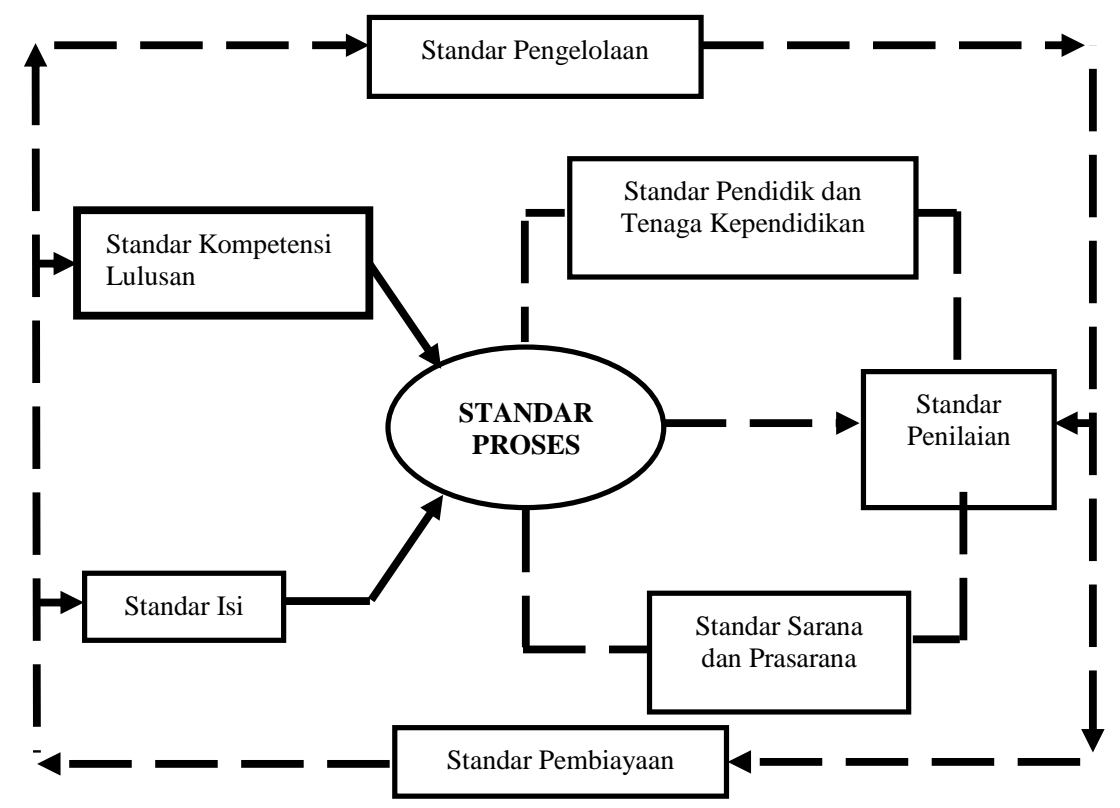

Gambar 2. Hubungan antara Standar Proses dengan Standar Lainnya

Gambar di atas menunjukan beberapa hal yang perlu diperhatikan yaitu; (1). Standar proses ditentukan oleh SKL dan SI, artinya standar proses dengan cara bagaimana, sehingga SKL dan SI dapat tercapai. Dengan kata lain standar proses adalah cara untuk mencapai SKL dan SI. (2). Efektivitas dan kelancaran standar proses dapat dipengaruhi atau bergantung kepada tenaga pendidik dan kependidikan serta sarana dan prasarana, karena tenaga pendidik dan kependidikan berfungsi sebagai pelaksana pendidikan, sedangkan sarana dan prasarana berfungsi sebagai alat dan media penyampaian pembelajaran. (3). Efektifitas standar proses akan di ukur oleh standar penilaian, dimana standar penilaian ini telah mengatur bagaimana mekanisme, prosedur dan instrument penilaian. (4). Keberhasilan pencapaian standar minimal pendidikan akan bergantung pada standar pengelolaan dan pembiayaan yang diatur oleh setiap jenjang satuan pendidikan, oleh karena ini maka setiap satuan pendidikan perlu mengatur 
standar pengelolaan dan standar pembiayaan. Dengan kata lain satuan pendidikan harus mengatur bagaimana me-manage agar pembelajaran dapat berlangsung dengan baik disertai dengan kebutuhan biaya yang diperlukan.

Sehingga Sanjaya (2009:10), mengatakan bahwa "standar proses merupakan jantungnya dalam sistem pendidikan. Bagaimanapun bagus dan idealnya standar kompetensi serta lengkapnya standar isi, namun jika tidak diimplementasikan kedalam proses, maka semuanya tidak berarti”. Jadi proses adalah action dari perencanaan-perancanaan yang telah buat berdasarkan SI, SKL dan KD.

\section{a. Standar Proses KTSP}

Pengimplikasian standar proses ini dilakukan oleh guru yang mempunyai peran yang amat penting. Hal ini karena guru merupakan pihak pertama yang berhubungan dengan pelaksanaan standar proses pembelajaran dikelas. Maka dalam penerapan standar proses setidaknya ada tiga hal yang harus dipahami oleh guru yang terdapat dalam Permendiknas No 41 Tahun 2007, yaitu: pemahaman dalam perencanaan proses pembelajaran, pemahaman dalam pelaksanaan proses pembelajaran, dan pemahaman dalam proses penilaian/evaluasi. Adapun isi dari standar proses bisa digambarkan sebagai berikut:

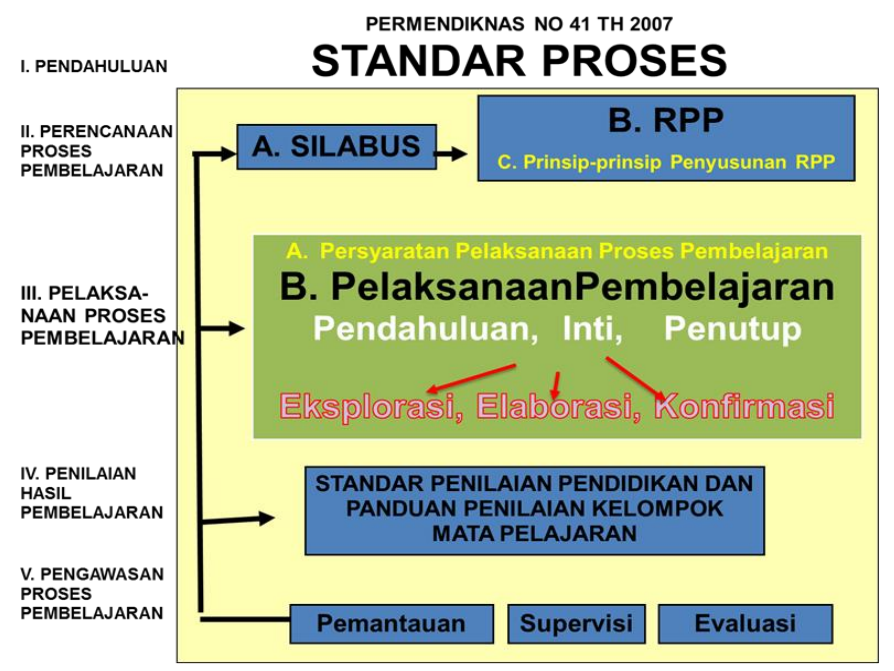

Gambar 3. Isi standar proses pembelajaran

Gambar diatas menjelaskan isi yang terkandung dalam standar proses pembelajaran yang tertera dalam permendiknas no 41 tahun 2007. Dari gambar tersebut terlihat bahwa satu sama lain saling melengkapi, dari mulai perencanaan, kemudian dituangkan menjadi sebuah tindakan pembelajaran, untuk mengukur keberhasilan dari pembelajaran dikelas maka berlanjut pada proses penilaian, akhirya semua proses dari mulai perencanaan sampai pada penilaian harus diawasi agar tetap berjalan sebagaimana mestinya. Berikut ini akan dibahas proses yang harus difahami oleh guru dalam pembelajaran berdasarkan pada standar proses pembelajaran. 
1) Perencanaan Proses Pembelajaran

Menurut Rosyada (Suwardi,2007:30), "Perencanaan pembelajaran itu meliputi rumusan tentang apa yang akan diajarkan, cara mengajar, dan tingkat penguasaan siswa terhadap bahan yang diajarkan". Secara sederhana perencanaan pembelajaran itu memuat materi yang diajarkan dalam kegiatan pembelajaran, strategi pembelajaran dan evaluasi yang digunakan untuk mengukur keberhasilan pembelajaran. Perencanaan proses pembelajaran dalam standar proses meliputi silabus dan rencana pelaksanaan pembelajaran (RPP) yang memuat identitas mata pelajaran, standar kompetensi (SK), kompetensi dasar (KD), indikator pencapaian kompetensi, tujuan pembelajaran, materi ajar, alokasi waktu, metode pembelajaran, kegiatan pembelajaran, penilaian hasil belajar, dan sumber belajar.

\section{2) Pelaksanaan Proses Pembelajaran}

Jiwani (2012: 141) mengemukakan bahwa "pelaksanaan proses pembelajaran di kelas tidak selalu sesuai dengan RPP yang telah disusun". Dalam kegiatan pembelajaran matematika, dimungkinkan adanya perubahan RPP. Perubahan RPP disebabkan karena guru mencoba metode baru tanpa menyusun RPP terlebih dahulu. Hal ini senada dengan English (2007) menyatakan bahwa pemikiran yang produktif dihasilkan bukan dengan memberikan langkah-langkah penyelesaian persoalan. Oleh karena itu, pembelajaran matematika perlu diselingi dengan metode-metode baru.

Pelaksanaan proses pembelajaran terbagi pada dua komponen yaitu, Prasyarat pelaksanaan proses pembelajaran yang terdiri dari syarat-syarat yang harus dipenuhi sebelum pembelajaran dilaksanakan dan pelaksanaan pembelajaran yang terdiri atas perwujudan atau implementasi dari RPP yang telah disusun pada saat proses perencanaan pembelajaran.

Prasyarat pelaksanaan proses pembelajaran yaitu: (1). Jumlah rombongan belajar untuk tingkat SD/MI 28 orang/kelas, SMP/MTs 32 siswa/kelas, SMA/MA 32 siswa/kelas, dan SMK/MAK 32 siswa/kelas. (2). Beban kerja pokok guru mecakup kegiatan merencanakan pembelajaran, melaksanakan pembelajaran, menilai hasil pembelajaran, membimbing dan melatih peserta didik, serta melaksanakan tugas tambahan, dilakukan minimal 24 (dua puluh empat) jam tatap muka dalam 1 (satu) minggu. (3). Pengguaan buku paket berdasarkan kesepakatan antara guru dengan komite sekolah yang telah ditetapkan oleh menteri, dengan rasio antara peserta didik dengan buku paket adalah 1:1 per mata pelajaran. Selain buku paket yang telah ditentukan dan disepakati, guru juga diharapkan menggunakan buku sumber lain dan membiasakan siswa mencari sumber lain. (4). Pengelolaan kelas, disini guru dituntut untuk menciptakan suasana pembelajaran yang menyenangkan buat siswa dari mulai mengatur tepat 
duduk, intonasi suara, menghargai pendapat siswa, menyesuaikan kecepatan penyampaian materi dengan kemampuan siswa, berpenampilan rapi, serta mengawali dan mengakhiri proses pembelajaran tepat pada waktunya.

Sedangkan pelaksanaan proses pembelajaran meliputi kegiatan pendahuluan, kegiatan inti, dan kegiatan penutup.

a) Kegiatan pendahuluan, dalam kegiatan pendahuluan, guru:

i. Menyiapkan peserta didik secara psikis dan fisik untuk mengikuti proses pembelajaran. Contohnya guru bertanya tentang kehadiran peserta didik, merapihkan tempat duduk siswa sehingga semuanya menjadi tertib.

ii. Mengajukan pertanyaan-pertanyaan yang mengaitkan pengetahuan sebelumnya dengan materi yang akan dipelajari. Misalnya mengajukan kuis tetang materi pada pertemuan sebelumnya $2-3$ menit untuk memancing ingatan peserta didik.

iii. Menjelaskan tujuan pembelajaran atau kompetensi dasar yang akan dicapai. Sehingga peserta didik tahu terget dari pertemuan saat itu.

iv. Menyampaikan cakupan materi dan penjelasan uraian kegiatan sesuai silabus.

b) Kegiatan inti

Kegiatan inti ini merupakan kegiatan utama dari proses pembelajaran. Dimana kegiatan ini bertujuan untuk mencapai KD, kegiatan ini dilakukan secara interaktif, inspiratif, menyenangkan, menantang, memotivasi peserta didik untuk berpartisipasi aktif, serta memberikan ruang yang cukup bagi prakarsa, kreativitas, dan kemandirian sesuai dengan bakat, minat dan perkembangan fisik serta psikologis peserta didik.

b. Standar Proses Kurikulum 2013

Desain pembelajaran disajikan dalam bentuk silabus rencana pelaksanaan pembelajaran (RPP), silabus dan RPP berpedoman pada standar isi dan standar kompetensi lulusan. Silabus dan RPP kemudian dilaksanakan pada proses pembelajaran atau disebut dengan pelaksanaan pembelajaran di kelas.

\section{Praktik Mengajar (Micro Teaching)}

Tim (2015: 2) Praktik mengajar yang selanjutnya akan disebut dengan micro teaching merupakan sebuah model pengajaran yang dikecilkan. Yakni jumlah peserta didiknya dibatasi antara 15 sampai 20 orang, ruang kelasnya kira-kira setengah dari ruangan kelas biasa. Waktu pelaksanaannya antara 10 - 15 menit ditambah evaluasi pembimbing sekitar 5 menit per mahasiswa.

Prima, Vol. 3, No. 1, Januari 2019, 67-84. 
Micro teaching menjadi mata kuliah wajib yang harus diikuti oleh mahasiswa calon guru. Mata kuliah ini berbobot dua SKS yang lebih bersifat praktis yakni mempraktikan teori-teori pengajaran. Calon guru matematika yang diperbolehkan mengambil mata kuliah micro teaching adalah mahasiswa yang sudah lulus mata kuliah Perkembangan peserta didik, kurikulum pembelajaran matematika, belajar dan pembelajaran matematika, perencanaan pembelajaran matematika, media pembelajaran matematika, evaluasi pembelajaran matematika dan pembelajaran matematika sekolah dasar dan menengah. Pada pelaksanaannya setiap 15 - 20 mahasiswa didampingi oleh satu orang dosen sebagai pembimbing yang bertugas mengarahkan mahasiswa.

Tim (2015:2) kuliah micro teaching bertujuan melatih mahasiswa agar memiliki keterampilan dasar dan khusus dalam proses mengajar, melatih mahasiswa agar memiliki sikap dan perilaku sebagai guru ideal, sebagai persiapan bagi calon guru sebelum benar-benar mengajar di depan kelas. Jika dilihat dari waktu pelaksanaan micro teaching, kuliah ini dijadikan salah satu syarat wajib bagi mahasiswa yang akan mengikuti praktik mengajar di sekolah (Praktik Pengalaman Lapangan). Karena pada semester VII mahasiswa akan disebarkan ke berbagai sekolah untuk melaksanakan PPL.

Teknis pelaksanaan micro teaching dilaksanakan selama sembilan pertemuan dengan ketentuan pertemuan pertama adalah pendahuluan, empat pertemuan berikutnya adalah latihan dan arahan dari pembimbing dan emapat pertemuan terakhir adalah ujian praktik mengajar. Adapun keterampilan yang dinilai adalah sebagai berikut:

a. Keterampilan perencanaan program pengajaran

b. Keterampilan prosedur mengajar

c. Keterampilan-keterampilan khusus dalam mengajar

d. Keterampilan menggunakan sumber, alat dan media pengajaran

e. Keterampilan menggunakan metode-metode mengajar

f. Keterampilan mengevaluasi hasil belajar.

Berdasarkan ketampilan di atas, maka hal-hal yang utama yang menjadi tugas mahasiswa adalah: mempelajari buku pedoman, membuat desain pembelajaran matematika sesuai dengan metode dan materi yang dipilih, menyiapkan alat peraga pembelajaran, berperan sebagai siswa saat mahasiswa lain sedang praktik, mengikuti seluruh kegiatan dan bersikap serta bertindak sebagaimana seorang guru yang ideal.

3. Proses Pembelajaran Matematika 
Tim (2005:723), matematika adalah ilmu tentang bilangan, hubungan antara bilangan, dan prosedur operasional yang digunakan dalam penyelesaian masalah mengenai bilangan. Ditinjau dari struktur dan urutan unsur-unsur pembentuknya, Purwoto (2003: 12) mengemukakan bahwa "Matematika adalah pengetahuan tentang pola keteraturan, pengetahuan tentang struktur yang terorganisasikan mulai dari unsur-unsur yang tidak didefinisikan ke unsur-unsur yang didefinisikan ke aksioma dan postulat dan akhirnya ke dalil".

Sedangkan menurut Suhendri (2011: 32) bahwa "matematika adalah ilmu tentang bilangan, bangun, hubungan-hubungan konsep, dan logika dengan menggunakan bahasa lambang atau simbol dalam menyelesaikan masalah-masalah dalam kehidupan sehari-hari”. Hakekat matematika oleh Ruseffendi (1988: 261), matematika adalah ilmu tentang pola keteraturan, ilmu tentang struktur yang terorganisir, mulai dari unsur yang tidak didefinisikan ke unsur yang didefinisikan ke aksioma atau postulat dan akhirnya ke dalil dan matematika adalah pelayan ilmu. Karena matematika timbul dari proses pemikiran manusia, tentu setiap orang dapat mempelajarinya, sehingga akan terasa sangat dangkal jika pemahaman matematika hanya didapat melalui hafalan saja.

Matematika berfungsi mengembangkan kemampuan menghitung, mengukur, menurunkan, dan menggunakan rumus matematika yang diperlukan dalam kehidupan sehari-hari melalui materi pengukuran dan geometri, aljabar, dan trigonometri. Matematika juga mengembangkan kemampuan mengkomunikasikan gagasan dengan bahasa melalui model matematika yang dapat berupa kalimat dan persamaan matematika, diagram, grafik atau tabel.

Mengingat pentingnya matematika, maka matematika perlu diajarkan disemua jenjang dan jenis sekolah. Menurut Runtukahu \& Kandou (Yuni dkk, 2015: 2) terdapat suatu kesadaran pada negara-negara maju maupun di negara berkembang bahwa pembelajaran matematika di sekolah belum melayani siswa dengan sepenuhnya. Oleh karena itu, salah satu upaya untuk mengembangkan pembelajaran matematika adalah dengan pembenahan kurikulum. Upaya lain adalah mengembangkan kreatifitas guru dalam mengelola pembelajaran yang dikemas dengan menggunakan model, metode atau strategi tertentu untuk memotivasi siswa agar senang belajar matematika.

Dari uraian di atas dapat disimpulkan bahwa matematika adalah ilmu tentang bilanganbilangan yang timbul dari pemikiran manusia yang berhubungan dengan ide, proses, pengkomunikasian dan penalaran. Matematika juga merupakan serangkaian metode untuk 
menarik kesimpulan serta mengkomunikasikan gagasan dengan bahasa dan tata cara tertentu yang memiliki keteraturan yang terstruktur.

Soedjadi (Windayana: 2007: 1) menyatakan bahwa pembelajaran matematika di sekolah merupakan salah satu komponen pendidikan yang tidak hanya mengembangkan kemampuan dan keterampilan menerapkan matematika, melainkan mengembangkan kemampuan memecahkan masalah. Proses pembelajaran matematika melalui tiga tahapan, yakni tahapan perencanaan pembelajaran, tahap pelaksanaan pembelajaran dan tahap pengevaluasian suatu tugas selama proses pembelajaran. Permedikbud nomor 65 tahun 2013 menyatakan:

"Proses Pembelajaran pada satuan pendidikan diselenggarakan secara interaktif, inspiratif, menyenangkan, menantang, memotivasi peserta didik untuk berpartisipasi aktif, serta memberikan ruang yang cukup bagi prakarsa, kreativitas, dan kemandirian sesuai dengan bakat, minat, dan perkembangan fisik serta psikologis peserta didik. Untuk itu setiap satuan pendidikan melakukan perencanaan pembelajaran, pelaksanaan proses pembelajaran serta penilaian proses pembelajaran untuk meningkatkan efisiensi dan efektivitas ketercapaian kompetensi lulusan"

Proses pembelajaran matematika bisa dikemas menjadi pembelajaran yang interaktif yakni pembelajaran yang memberikan kesempatan bagi siswa untuk menjalin interaksi yang bermakna dengan teman atau guru untuk mencapai kompetensi yang diharapkan. Menggunakan berbagai media pembelajaran yang kongkrit sampai media pembelajaran yang abstrak bisa menjadi alat bantu proses pembelajaran matematika yang interaktif. Sebagai salah satu contoh dikemukakan oleh Abidin (2014: 74) bahwa setelah menggunakan media pembelajaran matematika interaktif berbasis android diperoleh hasil bahwa siswa menjadi lebih termotivasi dalam melakukan hal-hal yang baik, termasuk dalam hal belajar dan rasa percaya diri siswa lebih meningkat.

Proses pembelajaran matematika yang menantang bermakna pembelajaran yang mana siswa dihadapkan pada masalah, kemungkinan baru dan persoalan matematika yang melibatkan kehidupan sehari-hari sesuai dengan tingkat usianya. Sehingga selain siswa menyelesaikan masalah siswa juga bisa merasakan betapa ertanya matematika dengan kehidupan nyata. Proses pembelajaran matematika harus memotivasi peserta didik untuk berpartisipasi aktif. Mendorong dan memberi semangat kepada siswa agar mampu mencapai prestasi dan berani mengekspresikan untuk berkompetisi. Menurut Siregar (2013:41)

"Guru mengajarkan ilmu dan kajian matematika bukan untuk menghasilkan peserta didik sebagai 'perpustakaan hidup' tentang ilmu dan kajian matematika tetapi lebih ditujukan 
untuk memampukan peserta didik berpikir secara rasional, berabstraksi dengan ide-ide, menemukan sendiri berbagai konsep dan prinsip matematika untuk diri mereka sendiri, meneladani seperti apa yang dilakukan oleh seorang sejarahwan, mereka turut mengambil bagian dalam proses mendapatkan pengetahuan"

Hasil penelitian Efrida (2012:139) menyatakan "kemampuan pemecahan masalah matematika siswa yang belajar dengan pendekatan PMRI lebih baik secara signifikan dari pada siswa yang belajar dengan pendekatan konvensional". Hasil penelitian lain oleh Suhendri (2015:112) menyatakan "hasil belajar matematika siswa yang diajar dengan metode pembelajaran problem solving lebih tinggi dari pada hasil belajar matematika siswa yang diajar dengan metode pembelajaran konvensional". Mahmuzah (2014:48), "peningkatan kemampuan berpikir kritis matematis siswa yang memperoleh pembelajaran dengan pendekatan problem posing secara signifikan lebih baik daripada siswa yang memperoleh pembelajaran konvensional baik secara keseluruhan maupun berdasarkan level siswa". Demikian juga Wahyuni (2013:40) meyatakan "kemampuan pemecahan masalah matematis siswa dengan pendekatan Open-ended lebih baik daripada pembelajaran konvensional, hal tersebut dilihat dari proses pembelajaran yang diawali pemberian masalah terbuka, membuat siswa lebih terbuka untuk menyelesaikan masalah matematika dari pengetahuan-pengetahuan yang diperoleh sebelumnya”.

Hasil-hasil penelitian di atas begitu jelas menujukan bahwa mengemas pembelajaran matematika dengan berbagai model, metode, pendekatan atau strategi akan mengembangkan berbagai kemampuan matemtika siswa yang diharapkan. Sehingga penguasaan proses pembelajaran matematika harus dipupuk mulai dari mahasiswa calon guru matematika, sehingga pada saat menjadi guru tidak hanya menggunakan pendekatan konvensional saja.

4. Analisis Implementasi Standar Proses Pembelajaran Guru Matematika

Rencana pelaksanaan pembelajaran dalam rangka menganalisa kemampuan calon guru matematika diperoleh hasiil sebagai berikut: (1) Rencana Pelaksanaan Pembelajaran yang disusun telah mengikuti format standar penyusunan RPP sesuai dengan kurikulumyang berlaku terdiri dari kurikulum KTSP dan Kurikulum 2013, sebagian mahasiswa kurang mengembangkan proses pembelajaran atau kegiatan inti, sampai pada penerapan model pembelajaran kurang maksimal ; (2) kemampuan menyusun Rencana Pelaksanaan Pembelajaran (RPP) guru matematika yang dijadikan objek penelitian sangat sesuai dengan format RPP yang digunakan atau dengan persentase 78,23 \%; (3) kesesuaian dengan pelaksanaan pembelajaran prosentase sebesar 77,67 \% pada kategori baik namun belum sampai

Prima, Vol. 3, No. 1, Januari 2019, 67-84. 
pada tahap evaluasi yang dicantumkan pada RPP (4) 56, $45 \%$ guru belum mengembangkan RPP sebagian besar hanya mencopy paste hanya sebagai syarat administrasi saja, belum disesuaikan dengan kondisi yang ada (4) Guru kurang mengembangkan aspek sikap baik penilaian sikap maupun mengembangkan atau meningkatkan akhlak siswa. Hal ini seiring dengan hasil penelitian (Haerul, M, 2016) yang dilakukan kepada guru fisika SMA di kabupaten Sinjai diperoleh sebagai berikut: kemampuan menyusun Rencana Pelaksanaan Pembelajaran (RPP) guru bersertifikasi bidang studi fisika Sekolah Menengah Atas di Kabupaten Sinjai sudah sangat sesuai atau dengan persentase 86,75\%; kesesuaian antara Rencana Pelaksanaan Pembelajaran (RPP) dengan implementasinya di kelas dengan persentase 85,33\% pada kategori sangat sesuai. Pada hasil observasi ini terlihat pula bahwa pelaksanaan pembelajaran dengan RPP yang dibuat oleh guru yang baru lulus sertifikasi masih sesuai dibandingkan dengan guru yang telah lama menyandang guru bersertifikasi pendidik.

\section{SIMPULAN DAN SARAN}

Berdasarkan hasil penelitian diperoleh bahwa tingkat kesesuaian pelaksanaan pembelajaran matematika pada prodi pendidikan matematika dengan kemampuan guru alumni prodi pendidikan matematika dalam melaksanakan standar proses pembelajaran pada kategori baik hal ini diperoleh dari analisis kemampuan alumni sebagai guru matematika yang mampu membuat RPP dengan baik, sesuai format dan mampu melaksanakannya. Adapun belum sempurnanya pengembangan RPP pada aspek kegiatan inti disebabkan jam terbang mengajar atau merasa kebingungan untuk mengembangkannya, diperlukan adanya pelatihan pengembangan RPP. Keberhasilan proses pembelajaran dipengaruhi oleh kemampuan membuat perencanaan yang baik, ini merupakan hal utama yang didambakan dalam melaksanakan pendidikan di sekolah sebagai upaya meningkatkan keberhasilan dalam pembelajaran matematika.

\section{DAFTAR PUSTAKA}

Abidin. dkk (2014). Pengembangan Media Pembelajaran Matematika Interaktif Berbasis Android Untuk Menumbuhkan Motivasi Belajar Anak Disleksia pada Materi Eksponensial di Kota Jambi. Jurnal Edumatica Volume 04 Nomor 02.

Ali, Mohammad. (2010). Metodologi dan Aplikasi Riset Pendidikan. Bandung: Pustaka Cendekia Utama.

BSNP. (2006). Peraturan Menteri Pendidikan Nasional Republik Indonesia Nomor 22 Tahun 2006 tentang Standar Isi untuk Satuan Pendidikan Dasar dan Menengah. Jakarta: Depdiknas. 
BSNP. (2007). Peraturan Menteri Pendidikan Nasional Republik Indonesia Nomor 41 Tahun 2007 Tentang Standar Proses untuk Satuan Pendidikan Dasar dan Menengah. Jakarta: Depdiknas

BSNP. (2013). Peraturan Menteri Pendidikan dan Kebudayaan Republik Indonesia Nomor 65 Tahun 2013 Tentang Standar Proses Pendidikan Dasar dan Menengah: Jakarta: Depdikbud.

BSNP. (2013). Peraturan Menteri Pendidikan dan Kebudayaan Republik Indonesia Nomor 64 Tahun 2013 Tentang Standar Isi. Jakarta: Depdikbud

Bungin, B. (2007). Penelitian Kualitatif. Jakarta: Prenada Media Group

Depdiknas. (2007). Undang-Undang No 16 Tahun 2007 Standar Kualifikasi Akademik Dan Kompetensi Guru. Jakarta: Depdiknas.

Diah, Anita Frasetyana dkk. (2015). Analisis Keterampilan Dasar Mengajar Mahasiswa Pendidikan Matematika dalam Pembelajaran Mikro. Jurnal Elektronik Pembelajaran Matematika Vol.3, No.4. Hal 383-394.

Efrida, Effie Muchlis. (2012). Pengaruh Pendekatan Pendidikan Matematika Realistik Indonesia (PMRI) Terhadap Perkembangan Kemampuan Pemecahan Masalah Siswa Kelas II SD Kartika 1.10 Padang. Jurnal Exacta, Vol. X. No. 2.

English, L. D. (2007). Cognitive Psychology and Mathematics Education: Reflections on the Past and The Future. Journal The Montana Mathematics Enthusiast. Monograph 2. Hal 119-126

Frengky (2008). Model Pembelajaran Matematika Siswa Kelas Satu Sekolah Dasar. Jurnal Psikologi Fakultas Psikologi Universitas Gadjah Mada Volume 35, No. 2, 151 - 163.

Haerul, M (2016) Analisis Kemampuan Membuat Rencana Pelaksanaan Pembelajaran (RPP) Guru Bersertifikasi Bidang Studi Fisika Sekolah Menengah Atas di Kabupaten Sinjai. S2 thesis, UNIVERSITAS NEGERI MAKASSAR, http://eprints.unm.ac.id/7034/ diunduh pada tanggal 12 Oktober 2018

Irjayanti, Runtyani Putri \& Heri, Rusgianto Santosa (2015). Keefektifan Strategi REACT Ditinjau dari Prestasi Belajar, Kemampuan Penyelesaian Masalah, Koneksi Matematis, Self Efficacy. Jurnal Riset Pendidikan Matematika. Volume 2 No 2. Hal 262 - 272

Jiwani, R. dkk. (2012). Implementasi Standar Proses dalam Pembelajaran Matematika dengan Analisis Context, Input, Process, Product. Unnes Journal of Mathematics Education Research 1 (2)

Juano, Asterius dan Pardjono. (2016). Pengaruh Pembelajaran Problem Posing Terhadap Kemampuan Berpikir Kritis dan Komunikasi Matematis Siswa Kelas V SD. Jurnal Prima Edukasia Volume 4- Nomor 1. Hal 46 - 53.

Kinati, Dini Fardah. dkk. (2013). Analisis Proses dan Kemampuan Berpikir Kreatif Matematis Melalui Pembelajaran Open-Ended. Unnes Journal of Mathematics Education Research 2 (2).

Lee, H. dan Hollebrands, K. (2008). Preparing to Teach Mathematics with Technology: An Integrated Approach to Developing Technological Pedagogical Content Knowledge. Journal Contemporary Issues in Technology and Teacher Education. Volume 8 No 4

Prima, Vol. 3, No. 1, Januari 2019, 67-84. 
Mahmuzah, Rifaatul. (2014). Peningkatan Kemampuan Berpikir Kritis dan Disposisi Matematis Siswa SMP dengan Menggunakan Pendekatan Problem Posing. Jurnal Didaktik Matematika Vol. 1, No. 2. Hal 43-53.

Moleong, L. J. (2006). Metodologi Penelitian Kualitatif. Bandung: Remaja Rosdakarya Mulyana, Endang. (2002). Pandangan Dan Penguasaan Guru Inti SLTP Terhadap Matematika

(Studi Kasus Pada Guru Inti Matematika SLTP di Bandung). Tesis pada SPs UPI Bandung: Tidak Dipublikasikan.

Mulyana, T. (2008). Pembelajaran Analitik Sintetik untuk Meningkatkan Kemampuan Berpikir Kritis dan Kreatif Matematik Siswa Sekolah Menengah Atas. Disertasi pada SPs UPI Bandung: Tidak Diterbitkan.

Mulyani, Sri. (2008). Pembelajaran Matematika dengan Alat Peraga Papan Berpasangan. EJurnal Dinas Pendidikan Kota Surabaya; Volume 5

National Council of Teachers of Mathematics. (1999). Curriculum and Evaluation Standards for School Mathematics. Reston, VA: Authur.

National Council of Teachers of Mathematics. (2000). Principles and Standards for School Mathematics. Reston, VA: NCTM.

Pratinuari, Karina. (2013). Keefektifan Pendekatan Open-Ended dengan Pembelajaran Kontekstual Terhadap Kemampuan Berpikir Kreatif. Unnes Journal of Mathematics Education Research 2 (1)

Purwoto. (2003). Strategi Pembelajaran Mengajar. Surakarta: UNS Press.

Ruseffendi E.T.(1988). Dasar-dasar Matematika Modern dan Kompetensi Untuk Guru. Bandung: Tarsito.

Salamah. (2006). Kemampuan Mengajar Guru Ditinjau dari Sikap Terhadap Profesi Guru, Pengalaman Mengajar, dan Konsep Diri Guru SD di Yogyakarta. Jurnal Skolar, Vol 7 , No. 1, hal 61-72.

Sanjaya, Wina. (2009). Strategi Pembelajaran Berorientasi Standar Proses Pendidikan. Jakarta: Kencana Prenada Media Group.

Siregar, Yulinda. (2013). Kompetensi Guru dalam Bidang Strategi Perencanaan dan Pembelajaran Matematika. Jurnal Formatif 3(1): 39-48.

Sobel, Max A. dan Evan M. Maletsky. (2004). Mengajar matematika sebuah buku sumber alat peraga, aktivitas dan strategi untuk guru matematika SD, SMP, SMA. Jakarta: Erlangga.

Sugiyono. (2015). Metode Penelitian Kualitatif. Bandung: Alfabeta.

Suhendri, Huri. (2011). Pengaruh Kecerdasan matematis-logis dan kemandirian belajar terhadap hasil belajar matematika. Jurnal Formatif, 1 (1): 29-39.

Suhendri, Huri. dan Mardalena, Tuti. (2015). Pengaruh Metode Pembelajaran Problem Solving Terhadap Hasil Belajar Matematika Ditinjau Dari Kemandirian Belajar. Jurnal Formatif 3(2): hal 105-114.

Susilo, Ahmadi dkk. (2015). Analisis Kemampuan Guru Matematika Dalam Mengimplementasikan Kurikulum 2013 Di Kota Semarang. Unnes Journal of Mathematics Education Research 4 (2).

Suwardi. (2007). Manajemen Pembelajaran Menciptakan Guru Kreatif dan Berkompetensi. Surabaya: STAIN Salatiga Press. 
Suwarsono. (2013). Pengembangan Kreativitas dalam Pembelajaran Matematika pada Kurikulum 2013. Prosiding SNMPM Universitas Sebelas Maret Volume 1 hal 1-24.

Tim MKBPM. (2001). Strategi Pembelajaran Matematika Kontemporer. UPI: JICA

Tim. (2005). Kamus Besar Bahasa Indonesia. Edisi Ketiga. Jakarta: Balai Pustaka.

Tim. (2015). Pedoman Kuliah Micro Teaching Fakultas Tarbiyah dan Keguruan. Bandung: UIN Sunan Gunung Djati Bandung.

Wahyuni, Desti. (2013). Kemampuan Pemecahan Masalah Matematis Dan Beliefs Siswa Pada Pembelajaran Open-Ended Dan Konvensional. Jurnal Edumatica Volume 03 Nomor 01. Hal $35-41$.

Wang, A. Y. 2011. "Contexts of Creative Thinking: A Comparison on Creative Performance of Student Teachers in Taiwan and the United States". Journal of International and CrossCultural Studies, Vol. 2, Issues I

Windayana, Husen. (2007). Pembelajaran Matematika Realistik dalam Meningkatkan Kemampuan Berpikir Logis, Kreatif, dan Kritis, Serta Komunikasi Matematik Siswa Sekolah Dasar. Jurnal Pendidikan Dasar Nomor: 8

Yulio, Rudi Arindiono \& Ramadhani, Nugrahadi. (2013). Perancangan Media Pembelajaran Interaktif Matematika untuk siswa kelas 5 SD. Jurnal Sains dan Seni POMITS Vol. 2, No.1

Yuni, Ni Nym Darjiani. (2015). Analisis Kesulitan-Kesulitan Belajar Matematika Siswa Kelas $V$ dalam Implementasi Kurikulum 2013 di SD Piloting Se-Kabupaten Gianyar Tahun Pelajaran 2014/2015. e-Journal PGSD Universitas Pendidikan Ganesha Jurusan PGSD Volume: 3 No: 1.

Prima, Vol. 3, No. 1, Januari 2019, 67-84. 